\title{
PHOTOSYNTHETIC ACCLIMATIZATION IN ZYGOTIC EMBRYO CULTURED PLANTLETS OF COCONUT (COCOS NUCIFERA L.)
}

\author{
By \\ S. Naresh Kumar ${ }^{1}$, V. Rajagopal ${ }^{1}$, and Anitha Karun ${ }^{2}$
}

\begin{abstract}
It is important to understand the physiological acclimatization process in order to provide the favorable growing conditions, to increase the survival rate and to produce vigorous seedlings for field planting for better establishment. These aspects assume significance because the embryo culture technique is used for germplasm collection in coconut. The zygotic embryos from eight month old selfed nuts from West Coast Tall (WCT) cultivar of coconut were collected for embryo culture. The field planted seedlings produced by embryo culture and those raised from nursery were compared for photosynthetic activity under field grown conditions. Photosynthetic and water relation parameters were studied in the embryo cultured plantlets at different stages of acclimatization under green net house conditions. The photosynthetic rate increased gradually during acclimation with maximum rate atfour months after transfer to pots (under 50\% shade; stage 4). The embryo cultured plantlets had higher photosynthetic rates compared to the nursery raised plants under field conditions. Transpiration rate increased with stage during acclimation. Embryo cultured plants had low transpiration rate as compared to the nursery raised plants. Consequently embrvo cultured plants had higher WUE (A/E). The WUE increased during acclimation. The Fv/Fm ratio increased gradually from 0.69 to 0.72 till stage 4 . The field-grown embryo culture plants had higher Fv/Fm compared to the nursery raised plant. This increase in $\mathrm{Fv} / \mathrm{Fm}$ during acclimation indicated the increase in photochemical activity and photosystem II electron transport efficiency. The study indicated increase in photosystem efficiency and carbon assimilation efficiency of embryo cultured plantlets of coconut during acclimatization.
\end{abstract}

\section{INTRODUCTION}

The importance of zygotic embryo culture in coconut is highlighted because of its immense potential as a means of collection and exchange of germplasm overseas. The protocols for germplasm collection through zygotic embryos are well established (Anitha Karun et al., 1993). It takes 12 to 18 months for transfer of zygotic embryos from test tube to grow into the plantlet ready for field planting. All the in vitro grown plantlets have to undergo physiological acclimation to be ready to survive in the nature (Van Huylenbroeck and Debergh, 1996). It is important to understand the physiological acclimation process in order to provide the optimal growing conditions. Thus to increase the survival rate and to obtain vigorous seedlings for field planting for better establishment. The importance is further highlighted because of the embryo culture technique is used for germplasm collection (Diekmann, 1997). Earlier study by Tniques et al., 1997 on photosynthetic ability of in vitro grown plantlets from zygotic embryos was confined only up to 6 weeks under different exposures to PAR. This study needs to be complemented at subsequent stages of seedling growth. Another study on embryo cultured coconut plantlets dealt with the chlorophyll and leaf morphological acclimatization (Ranasinghe et al.,1999). In the present study the aim was to generate further information and to, understand the photosynthetic ability, efficiency of photosystem 11 and water relations during the acclimation of zygotic embryo cultured plantlets through out the acclimation and field establishment periods. The comparison was made with the nursery ralsed seedlings of comparable age after field planting.

\footnotetext{
${ }^{1}$ Plant Physiology and Biochemistry Section; Central Plantation Crops Research Institute, Kasaragod, 671124 Kerala, India.

2 Biotechnology Section; Central Plantation Crops Research Institute, Kasaragod, 671124 Kerala, India.
} 


\section{MATERIALS AND METHODS}

The zygotic embryos from eight month old (after fertilization) selfed nuts from West Coast Tall (WCT) cultivar of coconut were collected for embryo culture. The field planted embryo cultured seedlings and the field planted nursery raised seedlings were used to compare the photosynthetic performance under field grown conditions. The embryo cultured seedlings were transferred from test tube to pots (filled with sterile sand and coir dust in same proportion) under laboratory conditions (20 $\mu \mathrm{mol} / \mathrm{m}^{2} / \mathrm{sec} P A R ; 75 \% R H$ and $22^{\circ} \mathrm{C}$ ). Individual plantlet was covered with polythene bags to, provide humidity. The humidity was reduced gradually by piercing holes on the surface of polythene cover. After acclimation under room conditions they were transferred to the deep green netted chamber with low light intensity $\left(75 \%\right.$ shade) and temperatures $\left(28^{\circ} \mathrm{C}\right)$ and humidity $(70 \%)$. Next stage was to allow the plantlets to grow under higher light intensities (50\% shade), temperatures $\left(30^{\circ} \mathrm{C}\right)$ and humidity $(60 \%)$. Leaf to air $V P D(L A V P D)$ at this stage was 0.5 to, 0.6 mbar.

The 8 month old embryos were cultured in Eeumens Y3 medium as per the protocol described by Anitha Karun et al, 1993. They were maintained under low light intensity (60 $\left.\mu \mathrm{mol} / \mathrm{m}^{2} / \mathrm{sec}\right)$, temperature $\left(22^{\circ} \mathrm{C}\right)$ and high humidity $(80 \%)$ conditions.

After transferring to the pots the plantlets were supplied with macro $Y_{2}$ medium at two weeks interval. The field grown seedlings were of two years age and were supplied with the recommended dose of NPK (165g:106g:400g) under irrigated conditions. The field conditions at the time of observations were $1300 \mu \mathrm{mol} / \mathrm{m}^{2} / \mathrm{sec}$ PAR, $35^{\circ} \mathrm{C}, 60 \%$ fore- noon $R H$ and $1-1.2 \mathrm{mbar} V P D$.

\section{Details of stages}

Observations were taken on five seedlings/stage in CRD. Following are the details of various stages of acclimatization process of the embryocultured seedlings.

Stage 1: Immediately after the removal of polybag under laboratory conditions. 2 months after transfer to pot from tube.

Stage 2: Plantlets under $75 \%$ shade in net house.

Stage 3: Plantlets under 50\% shade in net house.

Stage 4: Plantlets under 50\% shade in net house. 4 months after transfer to pots.

Stage 5: Seedlings in polybag, ready to be field planted

Stage 6: Field planted embryo cultured plant. 2 years after filed planting

Control (7): 2 year old field planted seednut sown plant.

The data were statistically analyzed and SEMs are presented.

\section{RESULTS AND DISCUSSION}

The growth conditions of the embryo cultured seedlings at various growth stages of acclimatization are presented in Table 1 and Figure 1. Observations on the growth parameters viz., number of leaves, collar girth and height of plantlet indicate the development of plantlets at the respective stage. The growth conditions distinctly varied during acclimatization as indicated by increased $P A R$ levels from $60 \mu \mathrm{mol} / \mathrm{m}^{2} / \mathrm{s}, 25^{\circ} \mathrm{C}$ under room conditions to $75 \mu \mathrm{mol} / \mathrm{m}^{2} / \mathrm{s}, 30^{\circ} \mathrm{C}$ under deep green net conditions and further to $450 \mu \mathrm{mol} / \mathrm{m}^{2} / \mathrm{s}, 30^{\circ} \mathrm{C}$ under green net conditions. The field 
grown plants were exposed to higher $P A R$ and temperatures. The $L A V P D$ was almost constant at 0.4 to 0.6 mbar during acclimation but it increased to $1.2 \mathrm{mbar}$ in field conditions. Ambient temperature increased from 30 to $35^{\circ} \mathrm{C}$ in acclimatization condition and then to $40^{\circ} \mathrm{C}$ under field conditions. The $\Delta \mathrm{T}$ increased from $-0.2^{\circ} \mathrm{C}$ under room conditions to $0.44^{\circ} \mathrm{C}$ during stage 2 and 3 of acclimation under green net conditions. It increased further to $0.62^{\circ} \mathrm{C}$ at stage 4 and then declined to $0.28^{\circ} \mathrm{C}$ at stage 5 . However, under field conditions, the $\Delta \mathrm{T}$ was as high as $5-5 \cdot 4^{0} \mathrm{C}$.

Growth of embryocultured plantlets was rapid from stage 3 as they were exposed to high $P A R$ an increase in number of leaves, cooler girth and plant height (Table 1). The photosynthetic rate increased gradually during acclimation and raised to maximum rate at stage 5, in fact maintained at higher rates than the plants grown under field conditions (Figure 2). The embryo cultured plantlets had higher photosynthetic rates compared to the nursery raised plants under field conditions. Correspondingly $\mathrm{Ci}$ decreased during acclimation indicating the increased efficiency of mesophyll tissue to perform photosynthetic activity. The $C i$ was maintained below $200 \mathrm{vpm}$ from stage 2 till field grown stage. Similar trend was observed for $\mathrm{Ci} / \mathrm{Ca}$ also. The stomatal conductance increased during acclimatization and the embryo cultured plants had higher gs compared to that of the nursery raised plants under field conditions. Interestingly, the transpiration rate, which also increased during acclimation was lower in embryo cultured plants compared to the nursery raise plants. Consequently the embryo cultured plants had higher $W U E(A / E)$. The WUE increased during acclimatization. This increase is mainly due to rapid increase in $P n$ rates compared to the increase in transpiration rates during acclimatization indicating the increasingly better utilization of available water for physiological processes during acclimatization.

The chlorophyll fluorescence parameter $F_{O}$ decreased till stage 4 of acclimatization and then increased at stage (Figure 3). However, under field conditions the $F_{O}$ levels decrease and were maintained at 250 counts. Decrease in Fo indicates increase in hardiness of the plantlet (Mohammed et al., 1995). The $F m$ value decreased till stage 3 and then increased. But the $F m$ counts were maintained low under field conditions compared to the acclimatization period. The $\mathrm{Fm}$ was higher in embryo cultured plant compared to the nursery raised plant. Almost similar trend was observed for $\mathrm{Fv}$ and Ft. The $F v / F m$ ratio increased gradually from 0.69 to 0.72 till stage 4 and then decreased at stage 5. The field grown embryo culture plant had higher $\mathrm{Fv} / \mathrm{Fm}$ compared to the nursery raised plant. This increase in $\mathrm{Fv} / \mathrm{Fm}$ during acclimatization also indicated the increase in photochemical activity and photosystem II electron transport efficiency. The photosystem II efficiency is higher under field grown conditions. The $F q$ indicating the fluorescence quenching capacity, increased till stage 2 and gradually decreased till stage 4 arid then increased in subsequent stages. The $t 1 / 2$ increased from stage 1 to stage 2 and remained same and decreased at stage 5 indicating that at constant actinic light level the photochemical activity was less under deep green conditions but increase during further stages of acclimatization. Increase in $t 1 / 2$ under field conditions indicate high rate of $P S I I$ activity and electron transport beyond $Q B$, thus generating the chemical energy-rich compounds for further use in dark reaction and the energy possibly used for other metabolic processes apart from $P n$. It is also possible due to increase in the size of the antenna of PSII.

The study indicates that during acclimatization, photosystem efficiency and carbon assimilation efficiency increases to attain efficiency similar to that of the nursery grown seedlings.

\section{ACKNOWLEDGEMENTS}

Authors are thankful to Dr. K.U.K. Nampoothiri, Director, CPCRI, for encouragement arid for providing facilities. 


\section{REFERENCES}

Anitha Karun, Shivashankar, S., Sajani, K.K and Saji, K.V. 1993. Field collection and in vitro germination of coconut embryos. J. Plantn. Crops 21 (Suppl.). 291-294.

Diekmann, M. 1997. The use of biotechnology for the after movement of coconut germplams. Paper presented at the International Symposium on Coconut Biotechnology, Merida, Dec., 1-5, 1997.pp 30.

Mohammed, G.H., Binder, W.D. and Gillies, S.L. 1995. Chlorophyll fluorescence: A review of its practical forestry application and instrumentation. Scan. J. For. Res. 10: $383-410$.

Ranasinghe, C.S., Weerakoon, L.K., Liyanage, Y.M.H. and Mathes, D.T. 1999. Physiological aspects of in vitro - grown coconut (Cocos nucifera L.) plants during acclimatization. Cord XV (2): 46-67.

Triques, K., Rival, A., Beul'e, T., Puard, M., Roy, J., Nato, A., Laver-ne, D., Havaux, M., Verdell, J., Sangare, A. and Hamon, S. (1997). Photosynthetic ability of in vitro grown coconut (Cocos nucifera L.) plantlets derived from zygotic embryos. Plant Sci., 127: 39-5 1.

Van Huylenbroeck, J.M. and Debergh, P.C. 1996. Physiological aspects in acclimatation of micropropagated plantlets. Plant Tiss. Cult. B iotech., 2 (3): 1 -3 ) 6- 141. 
Table 1: Growth conditions and growth parameters (mean of 5 values) of embryo Cultured plantlets at different stages of acclimatization

\begin{tabular}{|c|c|c|c|c|c|c|}
\hline Plantlet & \multicolumn{3}{|c|}{ Growth conditions } & \multicolumn{3}{c|}{ Growth parameters } \\
\hline stage & $\begin{array}{c}\text { PAR } \\
\left(\mu \mathrm{mol} / \mathrm{m}^{2} / \mathrm{sec}\right)\end{array}$ & Temperature & $\begin{array}{c}\text { RH } \\
(\%)\end{array}$ & $\begin{array}{c}\text { Number } \\
\text { Of leaves }\end{array}$ & $\begin{array}{c}\text { Collar } \\
\text { Girth }(\mathrm{cm})\end{array}$ & $\begin{array}{c}\text { Plantlet } \\
\text { Height } \\
(\mathrm{cm})\end{array}$ \\
\hline 1 & 60 & 22 & 75 & 2.7 & 4.5 & 21.5 \\
2 & 200 & 28 & 70 & 2.7 & 4.5 & 23.0 \\
3 & 400 & 30 & 70 & 3.2 & 6.2 & 40.0 \\
4 & 400 & 30 & 70 & 4.1 & 9.8 & 99.0 \\
5 & 400 & 30 & 70 & 8.0 & 11.0 & 120.0 \\
6 & 1300 & 35 & 60 & - & - & - \\
\hline
\end{tabular}

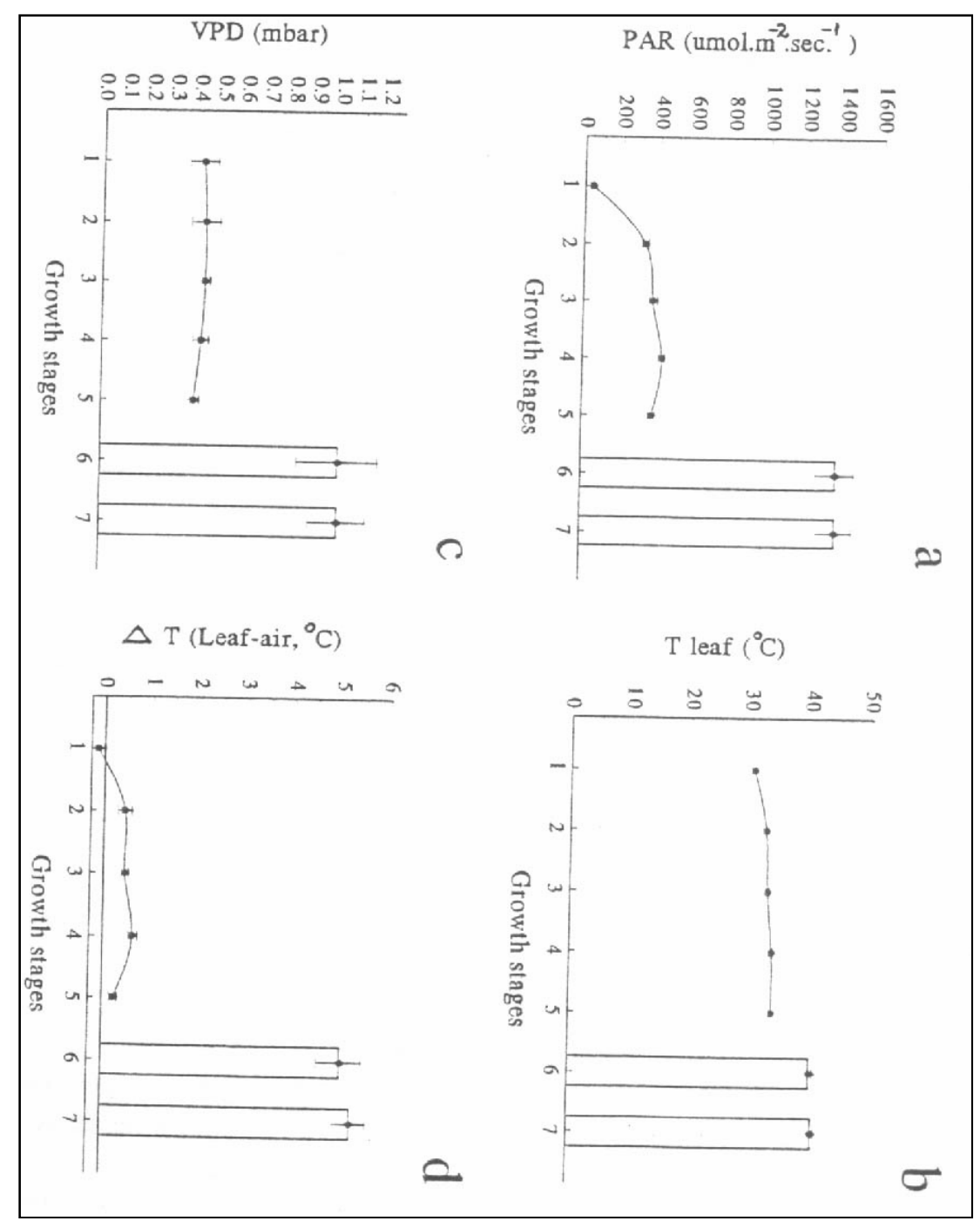

Figure 1: Photosynthetically active radiation (a), leaf temperature (b), leaf to air vapour pressure deficit (c) and Leaf to air temperature difference (d) during acclimatization of embryo cultured seedlings and also in field grown conditions (mean of 20 values/stage) 


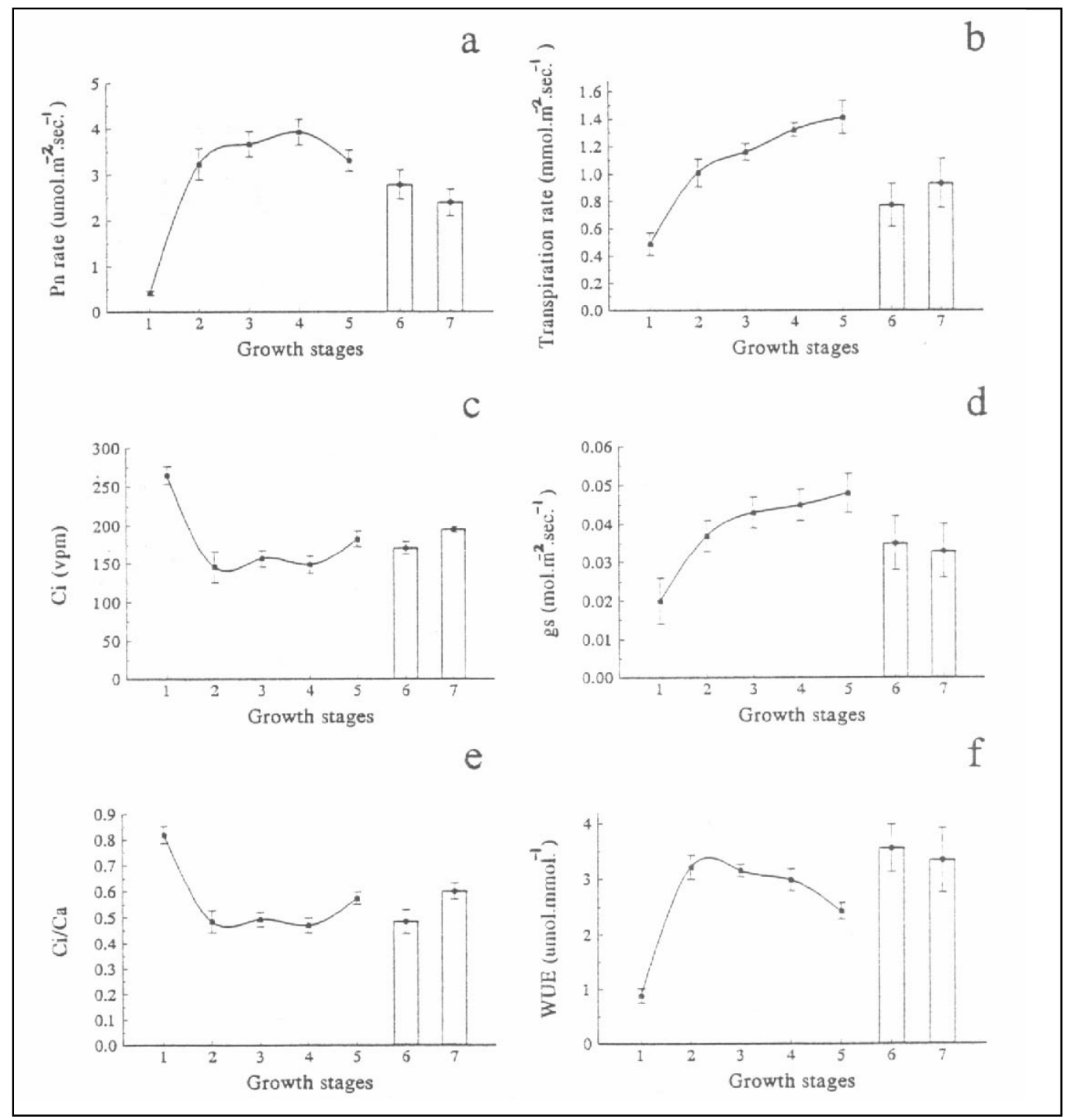

Figure 2: Photosynthetic rate (Pn; a), Transpiration rate (b), Sub-stomatal $\mathrm{CO}_{2}(\mathrm{Ci}$; c), Stomatal conductance $(g s ; \mathrm{d}), \mathrm{Ci} / \mathrm{Ca}$ (e) and instantaneous WUE (A/E; f) during acclimatization of embryo cultured seedlings and also in field grown conditions (mean of 20 values/stage) 


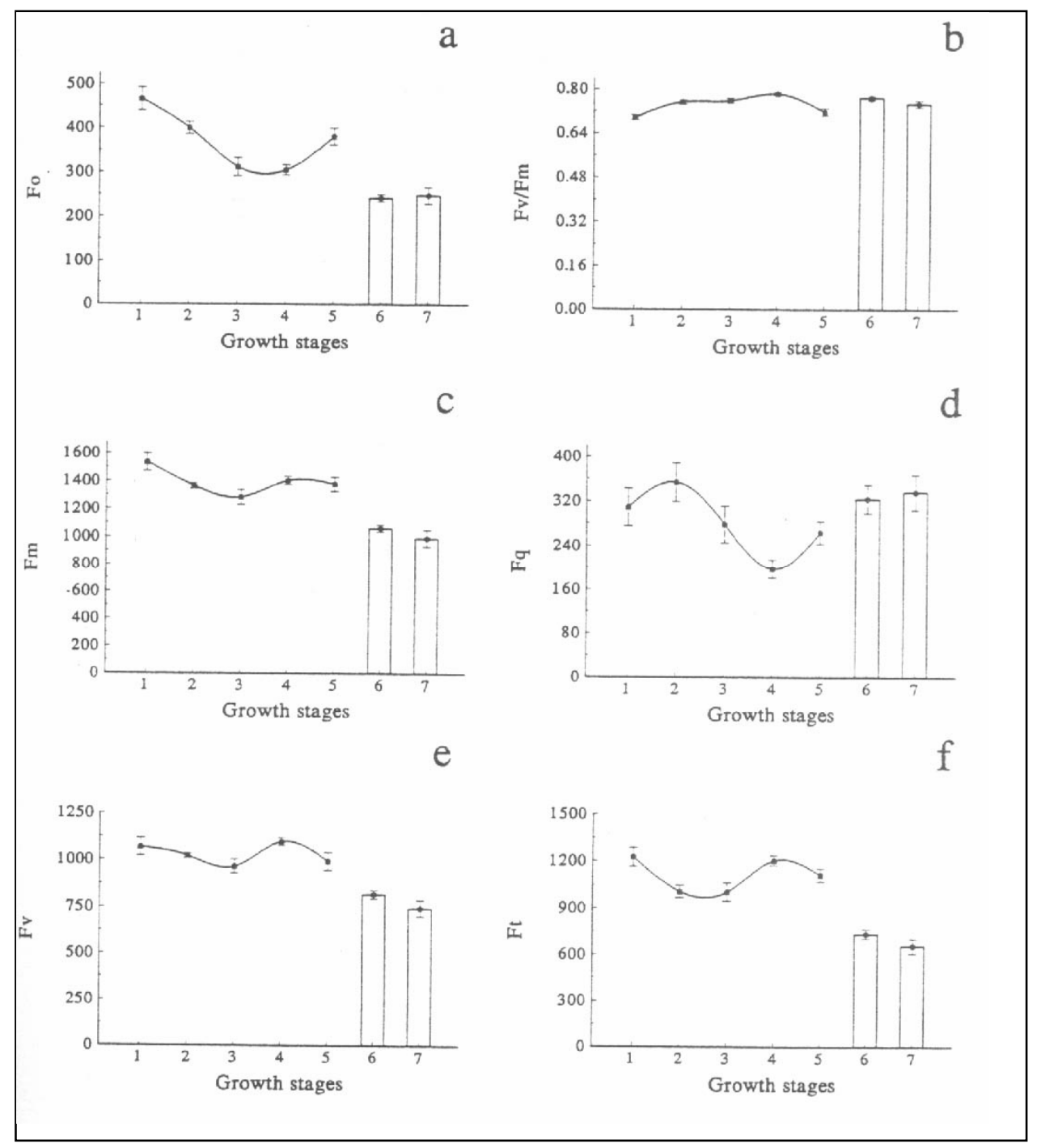

Fig. $3-\mathrm{a}$ to $\mathrm{f}$

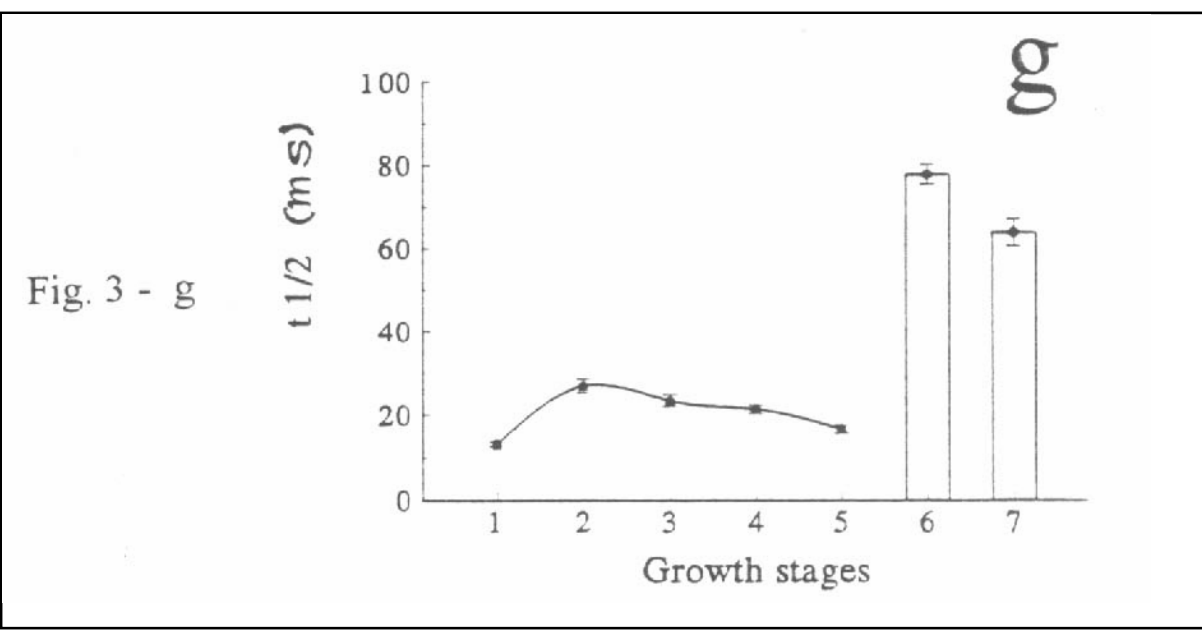

Figure 3: Chlorophyll fluorescence parameters Fo (a), Fv/Fm (b), Fm (c), Fq (d), Fv (e), Ft (f) and $\mathrm{t} 1 / 2(\mathrm{~g})$ during acclimatization of embryo cultured seedlings and also in field grown conditions (mean of 20 values/stage) 